\title{
Tax on excess profits from extraction of hydrocarbon feed as a completion tax maneuver in the oil and gas sector
}

\author{
Galina Semenova ${ }^{1,2},{ }^{*}$ \\ ${ }^{1}$ Plekhanov Russian University of Economics, Stremyanny per., 36, Moscow, Russia \\ ${ }^{2}$ Moscow Region State University, Radio str, 10A, 105005, Moscow, Russia
}

\begin{abstract}
The relevance of the paper is caused by the peculiarity of introducing a tax on excess profits from the extraction of hydrocarbon feed (hereinafter referred to as EPT), the calculation of tax taking into account the economics of developing hydrocarbon deposits for the entire investment period. The level of tax penalty depends on the profitability of each subsoil plot separately, which will allow the introduction of lowprofitable hydrocarbon deposits containing hard-to-recover reserves into development. Nowadays, a differentiated approach is being applied to setting the mineral extraction tax (hereinafter - MET) for oil depending on geographic and climatic conditions, complexity of field development, physical and chemical properties of oil (arctic conditions, offshore projects, new and developed deposits, high viscosity oils, hard-to-recover reserves and others). The introduction of EPT is caused by the need to engage oil reserves, which are currently unprofitable under the existing tax system, in commercial development. The introduction of EPT will allow for an increase in tax revenues both from an increase in the total volume of oil production and through more equitable taxation of ultra-efficient projects.
\end{abstract}

\section{Introduction}

A tax on excess profits from the extraction of hydrocarbon feed (EPT) was introduced in Russia from January 1, 2019 for new fields. It is aimed at removing additional income (excess profits) of oil companies from the sale of oil from new fields. The features of calculating and paying tax are established, and the fiscal conditions for hydrocarbon production are determined taking into account field development.

The excess profits from the extraction of hydrocarbon feed in the subsoil area is the estimated revenue from the sale of raw materials extracted in a particular subsoil area, successively reduced by the amount of actual production costs and the estimated costs.

The following types of extracted minerals belong to hydrocarbon feed: dehydrated, desalted and stabilized oil; gas condensate that has undergone field preparation technology

* Corresponding author: doptaganka@yandex.ru 
in accordance with the technical design of the field development before being sent for processing; natural combustible gas (dissolved gas or a mixture of dissolved gas and gas from a gas cap) from all types of hydrocarbon deposits produced through oil wells (associated gas); natural combustible gas, with the exception of associated gas.

The following activities are involved in the development of a subsoil area for the extraction of such raw materials: the search and assessment of hydrocarbon deposits, exploration, production (extraction from the subsoil) of hydrocarbon feed; transportation of hydrocarbons; preparation of hydrocarbon feed - the separation of any mixture in a gaseous and (or) liquid state containing hydrocarbon feed into derivative mixtures containing certain types of hydrocarbon feed; bringing hydrocarbon feed (including at third party facilities) to a quality at which such raw material is recognized as a commodity; the storage of hydrocarbons; the creation of associated gas utilization (processing) facilities; leasing to a person providing services (performing work) to a taxpayer, related to the implementation of one or more of the above types of activities.

There are four groups of subsoil areas:

Group 1. New licensed subsoil areas ("greenfields") located in whole or in part on the Russian part of the bottom of the Caspian Sea, in the Republic of Sakha (Yakutia), Irkutsk Region, Krasnoyarsk Territory, Yamalo-Nenets Autonomous Okrug (District), to the north of 65 degrees north latitude or partially within the borders of the Nenets Autonomous Okrug, with a certain degree of depletion. This group also includes subsoil areas located in the indicated regions, the oil reserves of which were first put on the state balance of mineral reserves after January 1, 2017.

Group 2. New subsoil areas, including hydrocarbon reserves of deposits specified in the unified Commodity Nomenclature of the Eurasian Economic Union as of January 1, 2018

Group 3. The developed subsoil areas ("brownfields"), located in whole or in part in the Khanty-Mansiysk and Yamalo-Nenets Autonomous Okrugs, the Republic of Komi and the Tyumen Region with a certain degree of depletion of oil reserves.

Group 4. New subsoil areas located in whole or in part in the Khanty-Mansiysk and Yamalo-Nenets Autonomous Okrugs, the Republic of Komi and the Tyumen Region with a certain degree of depletion of oil reserves.

Moreover, in relation to licensed subsoil areas of groups 3 and 4, the Tax Code of the Russian Federation shows the exact geographical coordinates of licensed subsoil areas, taking into account the following:

- a restriction on the total production of oil and gas condensate for 2016 for all subsoil areas of group 3 in the amount of not more than 15 million tons.

- a restriction on the total initial recoverable reserves of oil and gas condensate as of January 1, 2017 for all subsoil areas of group 4 in the amount of not more than 150 million tons.

Excessive profits is defined as the difference between the estimated revenue from hydrocarbon production and the sum of the total actual and estimated costs of hydrocarbon production in the licensed subsoil area.

\section{Materials and Methods}

The tax base for the calculation of EPT is the monetary expression of the additional income from hydrocarbon production.

If the tax base takes a negative value, then it is recognized as 0 . However, the tax regime for EPT accounts for losses incurred in excess of actual and estimated expenses over the estimated revenue. Accounting for the resulting loss is carried out by reducing the tax base by their amount, as well as losses of previous periods. 
The estimated revenue from the production of hydrocarbon feed is the revenue from the sale of hydrocarbon feed extracted in the subsoil area. The tax (reporting) period is the sum of the estimated revenue from the sale of hydrocarbon feed extracted in the subsoil area for each calendar month of the tax (reporting) period.

Estimated revenue is determined by the cumulative total from the beginning of the year for each month according to the following formula

$$
\text { Re-month }=\text { Poil x Voc x Rub x Ko }+ \text { Pgas x Vgas }+0.95 \text { x Pag x Vag }
$$

Where:

Re-month - estimated revenue from the sale of produced hydrocarbon feed per month;

Poil - monthly average price level for Urals oil in world markets, expressed in US dollars per barrel;

Voc - the amount of oil and gas condensate extracted in the subsoil area per month, expressed in tons;

Rub - the average monthly value of the US dollar to the Russian ruble;

$\mathrm{Ko}$ - the conversion rate of metric tons to barrels, equal to 7.3;

Pgas - the gas price set by the authorized federal executive body, which carries out the functions of adopting regulatory legal acts in the field of state regulation of prices (tariffs) for goods (services) for the respective production region, per calendar month, expressed in rubles per thousand cubic meters.

Vgas - the amount of natural gas produced per month in the subsoil area, expressed in thousands of cubic meters, with the exception of natural gas injected into the reservoir to maintain pressure during production in accordance with the technical project of the field development;

Pag - the price of associated gas, defined as the arithmetic average of the actual selling prices of associated gas per month, in rubles per thousand cubic meters, but not less than Pgas defined for the corresponding month;

Vag - the amount of associated gas produced in the subsoil area, with the exception of associated gas injected into the reservoir to maintain pressure during production in accordance with the technical project of the field development, expressed in thousands of cubic meters.

The amount of estimated costs in the subsoil area in the form of a calculated export customs duty on oil and gas condensate for the tax (reporting) period is determined by summing up such expenses for each month of the tax (reporting) period. The estimated export customs duty on oil and gas condensate is determined for each month as the product of the following indicators:

$$
\text { De }=\text { EDoil x Rub x }(\text { Voil }+ \text { Vgc })
$$

Where:

EDoil - the actual rate of export customs duty on oil produced in the subsoil area, established in the corresponding month and expressed in US dollars per ton;

Rub - the average monthly value of the US dollar to the Russian ruble;

Voil and Vgc - the amount of oil and gas condensate produced in the subsoil area for a calendar month, expressed in tons.

Calculation of MET on extracted oil. Organizations that switched to EPT calculate MET on oil according to the following formula:

$$
\mathrm{MET}=\operatorname{Tr} \mathrm{x} \text { KEPT, }
$$

Where:

$\operatorname{Tr}$ - tax rate is 1 ruble per 1 ton of oil. 


$$
\mathrm{KEPT}=0.5 \times(\text { Poil }-15) \times \mathrm{Rub} \times 7.3 \times \mathrm{Kt}-\mathrm{ED} \times \mathrm{Rub},
$$

Where:

Poil - monthly average price level for Urals oil, expressed in US dollars per barrel;

Rub - the average monthly value of the US dollar to the Russian ruble;

$\mathrm{Kt}$ - the coefficient characterizing the period of time that has passed since the date of commencement of industrial oil production in the subsoil areas. This coefficient takes the following values:

For groups 1 and 2 of subsoil areas:

0.4 - starting from the month of calculating EPT on extracted oil in the subsoil area and after 5 years following the year of commencement of industrial oil production in the subsoil area;

0.6 - starting from the sixth year following the year of commencement of industrial oil production in the subsoil area;

0.8 - starting from the seventh year following the year of commencement of industrial oil production in the subsoil area;

1 - starting from the eighth year following the year of commencement of industrial oil production in the subsoil area.

For group 4 of subsoil areas:

0.5 - starting from the month of calculating EPT on extracted oil in the subsoil area and after 1 year following the year of commencement of industrial oil production in the subsoil area;

0.75 - starting from the second year following the year of commencement of industrial oil production in the subsoil area;

1 - starting from the third year following the year of commencement of industrial oil production in the subsoil area.

For group 3 of subsoil areas, the coefficient Kt is 1 .

ED - the rate of export customs duty on oil extracted in the subsoil area, established in the corresponding month and expressed in US dollars per ton.

The tax rate is $50 \%$. The tax on excess profits from the extraction of hydrocarbon feed (EPT) is calculated as the percentage of the tax base corresponding to the tax rate.

$$
\mathrm{EPT}=\operatorname{Tr} \mathrm{x} \mathrm{TB},
$$

Where:

TB - tax base,

$\operatorname{Tr}-$ tax rate, $\%$

\section{Results}

In 2019, Russia broke the post-Soviet oil record. Oil production amounted to 560.2 million tons in 2019 (according to the Central Dispatching Department of Fuel Energy Complex" (CDU TEK)), which is higher than the levels of 2017 and 2018, when it was at its maximum since the beginning of post-Soviet times - 549 and 556 million tons, respectively. The Soviet oil industry set a record for production of oil and condensate in 1987, when it reached 569.5 million tons. After that, it gradually decreased. In 1996, it fell to 303 million tons.

According to the forecast of the Ministry of Energy of the Russian Federation, Russian oil production may face a drop in the coming years if the taxation of the industry is not reformed. According to the Minister of Energy Alexander Novak, the Russian oil business bears the highest tax burden in the world, which reaches $70 \%$ of the company's revenue. 
Almost half of the oil reserves in Russia today are unprofitable for development under the current fiscal system.

Russia occupies $12.8 \%$ of the territory of our planet; it has significant world-wide natural resources of hydrocarbon feed (Table 1).

Table 1. Resources of the main energy sources and sources of hydrocarbons in Russia.

\begin{tabular}{|c|c|c|c|}
\hline $\begin{array}{c}\text { Type of } \\
\text { hydrocarbon feed }\end{array}$ & $\begin{array}{c}\text { Explored } \\
\text { reserves }\end{array}$ & $\begin{array}{c}\text { Share of world } \\
\text { resources, \% }\end{array}$ & Annual production \\
\hline Oil & 7 billion tons & 5 & 300 million tons \\
\hline Natural gas & 236 trillion $\mathrm{m}^{3}$ & 34 & 600 billion $\mathrm{m}^{3}$ \\
\hline Coal & 5.3 trillion tons & $20 \%$ coal & 300 million tons \\
& & $32 \%$ brown coal & \\
\hline
\end{tabular}

The cost of all extracted minerals is estimated at 95-105 billion dollars, of which 85-90 billion dollars fall to oil and gas. At the same time, in the cost balance, hydrocarbon feed and products of its processing account for $40-45 \%$.

In the global trade balance of hydrocarbons, the share of Russian exports fluctuates around $8 \%$ for oil and $36 \%$ for gas. Maintaining such high rates is still possible due to the low level of domestic consumption.

The analysis shows that about $40 \%$ of the funds of industrial enterprises and $13 \%$ of the book value of fixed assets of the Russian economy are concentrated precisely in the field of subsoil use. Mining and exploration industries provide at least $25 \%$ of GDP and about $50 \%$ of the country's exports. These data convincingly show that the country's economic wellbeing largely depends on the state and effectiveness of the use of the national mineral resource base.

Today, the introduction of EPT in Russia is caused by the completion of the tax maneuver in the oil and gas sector. Although this tax is new, excess profits in the amount of 100,901 million rubles have already arrived to the budget system of the Russian Federation over the past ten months (table 2).

Table 2. Revenues from tax on excess profits from the extraction of hydrocarbon feed to the budget system of the Russian Federation on 01.11.2019, million rubles (According to the Federal Tax Service of Russia.

https://www.nalog.ru/rn50/related_activities/statistics_and_analytics/forms/8824368/).

\begin{tabular}{|l|c|c|}
\hline \multicolumn{1}{|c|}{ Indicators } & $\begin{array}{c}\text { Revenues on } \\
\mathbf{0 1 . 1 1 . 2 0 1 9}\end{array}$ & $\begin{array}{c}\text { The share of tax on excess profits from } \\
\text { hydrocarbon production in the subsoil } \\
\text { areas to the general EPT, \% }\end{array}$ \\
\hline $\begin{array}{l}\text { Tax on additional income from } \\
\text { hydrocarbon production }\end{array}$ & 100901 & 100 \\
\hline including: & 1115 & 1.1 \\
\hline $\begin{array}{l}\text { Tax on excess profits from hydrocarbon } \\
\text { production for taxpayers belonging to } \\
\text { the first group of subsoil areas }\end{array}$ & 35715 & 35.4 \\
\hline $\begin{array}{l}\text { Tax on excess profits from hydrocarbon } \\
\text { production for taxpayers belonging to } \\
\text { the second group of subsoil areas }\end{array}$ & 62548 & 62.0 \\
\hline $\begin{array}{l}\text { Tax on excess profits from hydrocarbon } \\
\text { production for taxpayers belonging to } \\
\text { the third group of subsoil areas }\end{array}$ & 1523 & 1.5 \\
\hline $\begin{array}{l}\text { Tax on excess profits from hydrocarbon } \\
\text { production for taxpayers belonging to } \\
\text { the fourth group of subsoil areas }\end{array}$ & \multicolumn{2}{|c|}{} \\
\hline
\end{tabular}

In the developed subsoil areas ("brownfields") located in whole or in part in the KhantyMansiysk and Yamalo-Nenets Autonomous Okrugs, the Republic of Komi and the Tyumen 
Region with a certain degree of depletion of oil reserves, tax revenues from hydrocarbon production for 10 months of 2019 amounted to $62 \%$ of the total amount of all EPT incomes.

In new subsoil areas, including hydrocarbon reserves of deposits specified in the unified Commodity Nomenclature of the Eurasian Economic Union, tax revenues from hydrocarbon production $-35.4 \%$ [1].

In Russia, new subsoil areas are being developed, but it is necessary to pay attention to the environment. As you know, the main source of hydrocarbon feed and the main energy carrier in Russia is oil. The enterprises of the fuel and energy sector of Russia, including those involved in the extraction and transportation of oil, despite a decrease in production volumes compared with 1990, remain the largest source of environmental pollution in industry. Environmental problems begin already at the stage of extraction of crude oil and its transportation to the consumer. More than 60 major accidents and about 20 thousand cases accompanied by significant oil spills, oil ingress into water bodies, loss of life, and large material losses occur annually.

Therefore, in the development of hydrocarbon production sites, enterprises must take environmental protection measures and compensate for damage caused in addition to paying tax. It is necessary to introduce new innovative technologies to improve environmental efficiency. Using the services of environmental specialists, this will reduce the tax rate on environmental tax [2].

Nowadays, enterprises are not actively engaged in environmental innovations. They believe that it is better to pollute the environment with waste, burn waste, and dump waste material into rivers. Indeed, if they do not have the necessary resources or cannot carry out research and development, the development of other enterprises can be acquired, and the presence of environmental taxes should stimulate the introduction of the most modern scientific technologies $[3,4]$.

\section{Conclusions}

Realization of the country's oil and gas potential requires huge capital investments not only in the search and assessment of deposits in new remote, inaccessible areas, but also in their industrial arrangement and the creation of specialized infrastructure. A solution to this problem is impossible without strengthening state support for the oil and gas sector and improving state regulation of subsoil use, which has significantly weakened in recent years. To this end, Russia introduced EPT.

The raw material base of the Russian gas industry is characterized by an exceptionally high concentration of explored reserves in the main gas-bearing regions in a relatively small number of the largest and most unique fields. Almost $78 \%$ of the explored reserves are concentrated in Western Siberia, and about $74 \%$ of them are in 23 unique fields, each of which contains over 500 billion $\mathrm{m}^{3}$ of gas. Among them, the Urengoyskoye field with reserves (residual) of 7.2 trillion. $\mathrm{m}^{3}$, Yamburgskoye - 4.1 trillion. $\mathrm{m}^{3}$, Bovanenkovskoye 4.4 trillion. $\mathrm{m}^{3}$, and five other fields with reserves of more than 1 trillion. $\mathrm{m}^{3}$ in each.

The analysis and forecast of the development of the oil and gas industry in Russia indicate a further increase of global consumption of energy resources in the coming decades, primarily hydrocarbons. In the regional plan, the demand for oil and gas is growing most rapidly in the Asia-Pacific countries, mainly in China, India, Indonesia, and the Philippines. At the same time, only a few large raw hydrocarbon bases remain globally, due to which it is possible to satisfy prospective energy needs. These are the politically unstable Middle East, economically and technologically inaccessible and geologically poorly studied shelves of the Arctic seas, as well as the North of Western Siberia (YamaloNenets and Khanty-Mansi Autonomous Okrugs) and the territory of the Siberian Platform (Irkutsk Region, the united Krasnoyarsk Territory, Republic of Sakha). 44.1\% of the 
explored reserves are concentrated in the developed fields, 33\% in those prepared for development, and over $22 \%$ - in the exploring ones. Therefore, the development and exploitation of new hydrocarbon production areas is a tax maneuver in the oil and gas sector.

\section{References}

1. D.N. Dorogutina, Young scientist 42, 84-87 (2017)

2. G. Semenova, E3S Web of Conferences, TRACEE-2018 91, 08046 (2019) DOI: $10.1051 / \mathrm{e} 3$ sconf $/ 20199108046$

3. G. Semenova, E3S Web of Conferences, TRACEE-2018 91, 08047 (2019) DOI: 10.1051/e3sconf/20199108047

4. E. Vasilyeva, A. Mottaeva , E3S Web of Conferences, 91,08051, (2019) doi.org/10.1051/e3sconf /20199108051 